\title{
Awareness and Real Use of Reading Strategies
}

\author{
Ryusuke Yamato \\ Hokuriku University
}

This study uses a newly developed questionnaire to investigate the following three research questions dealing with Japanese learner awareness and use of strategies for reading English as a foreign language (EFL) texts: (1) What factors are extracted through factor analysis indicating the degree of EFL learners' awareness of reading strategies; (2) How do two types of strategy awareness, use-awareness and effect-awareness, interact with each other for better comprehension; and (3) What is the relationship between the learners' level of strategy awareness and their English proficiency level? Analysis of questionnaire data collected from 242 Japanese university EFL students suggests that three of the five extracted factors fit an interactive reading model. Although clear relationships were not observed between either type of strategy awareness and proficiency level, learners reported more frequent use of strategies they perceived to be less effective than strategies they perceived as effective. Based on these findings, classroom implications for strategy instruction are discussed.

本論は、新しく開発された質問紙を用いて、読解ストラテジーに関して日本人英語学習 者がどのような認識を持ち、どのように使っているかを考察する。特に考察する点は次の 三点である。（1）因子分析により、日本人英語学習者が持つ読解ストラテジーの使用認 識に関してどのような因子が抽出されるか。（2）二種類のメ夕認知（使用認識と効果認 識）のスタイルが、より良い読解につながるか。（3）学習者のストラテジーの認識と習 熟度との関係はどのようなものか。242名の大学生から得られたデー夕の分析から、 読解ストラテジーに関して抽出された因子の多くが相互読解モデルに適合すること（2） ストラテジーの認識と習熟度との間にははっきりした関係は本研究では認められなかった が、学習者が効果的でないと考えるストラテジーを頻繁に使用し、効果的と考えるストラ テジーをあまり使用していないという認識をしていることが示された。これらの分析に基 づき、本論はストラテジー指導のための提案をいくつか行なった。

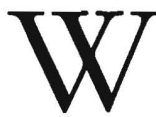

ith the rising interest in learning processes, achieving learner autonomy has become a major goal in language instruction. Many teachers agree that the appropriate use of language learning strategies serves to accomplish this goal. Researchers (e.g., Baker \& Brown, 1984; Block, 1986; Barnett, 1988; Carrell, 1989) have reported that learners' awareness ${ }^{1}$ of strategy use influences both comprehension 
and production in the target language. Such circumstances encourage language teachers to seek methods of strategy instruction within a theoretical framework. In their quest, however, teachers may encounter difficulties because of discrepancies existing among researchers regarding definitions and classifications of learning strategies.

One discrepancy is found between a classification model proposed in language education, e.g., the Strategic Inventory of Language Learning (SILL) by Oxford (1990) and one proposed in cognitive psychology research (e.g., O'Malley \& Chamot, 1990). SILL employs six strategy categories: memory, cognitive, compensatory, metacognitive, affective, and social, whereas the cognitive psychology model includes only three: metacognitive, cognitive, and affective/social. However, this discrepancy is not considered to be so serious because considerable overlap is observed between the two models when their subclassification items are closely examined. ${ }^{2}$

Another discrepancy derives from different elicitation methods and seems more serious. With respect to reading, for example, a large gap exists between reading strategies investigated through think-aloud protocols (e.g., Hosenfeld, 1977; Block, 1986) and those investigated by analysis of structured questionnaires such as the SILL. This gap may be construed as natural because, "strategy questionnaires do not typically provide detailed, task-related information" (Oxford, 1996, p. 247) and the SILL is an inventory of language learning strategies in general, not an inventory of reading strategies. However, this discrepancy presents a problem for many English teachers in Japan who want to instruct students on the use of strategies for the four skills of reading, writing, listening and speaking, skills which are often taught independently at high schools and colleges in Japan.

As for the learners' awareness of language learning strategies, a number of studies have discussed the relationship between learner awareness of their own strategy use, use-awareness, and language proficiency, but relatively few studies have investigated whether or not the learners' awareness of strategy effectiveness is related to proficiency. Even if learners' awareness of strategy effectiveness in general (effect-awareness) is not as influential as their awareness of their own use of strategies (use-awareness), it is of interest to examine how these two types of learners' awareness might interact with each other to enhance reading comprehension.

In this context, a study using a newly developed strategy questionnaire was conducted to investigate the level of awareness which Japanese EFL learners at different proficiency levels have of different reading strategies and also their awareness of their own use of reading strategies. Based on analysis of data collected from 242 Japanese university EFL students, some classroom implications for strategy training are presented. 


\section{Research on Learners'Awareness of Reading Strategies}

Baker and Brown's 1984 publication is considered a starting point for studies on learners' awareness of reading strategies in second language acquisition. These authors suggested that "declarative knowledge," or conscious awareness of effective strategies, is different from "procedural knowledge," or the ability to use such strategies, with the former preceding the latter. Barnett (1988) investigated the relationship between strategy use, awareness of strategy use, and reading comprehension. . She suggested that not only students who use strategies effectively, but also those who think they use strategies tend to comprehend text better than students who neither use nor think they use strategies.

Building on the results of Barnett's study, Carrell (1989) ${ }^{3}$ used a questionnaire with a five-point Likert scale and found that top-down strategies are related to second language reading performance, whereas bottom-up strategies are more related to foreign language reading performance. A research group at Tsudajuku (1992) conducted similar questionnaire research with Japanese university English as a Foreign Language (EFL) students as subjects. Factor analysis of the data revealed that good readers tend to use top-down strategies, whereas poor readers use bottom-up strategies. Yamato (1997) more closely examined the relationship between proficiency level and strategy awareness. The subjects of Yamato's study were 17 to 18 year-old Japanese high school students. Using a methodology similar to the Tsudajuku study, Yamato suggested that the situation may be more complicated because not all top-down strategies are positively related to proficiency level and some bottom-up strategies may enhance reading comprehension.

\section{Limitations of Questionnaire Research}

One problem with studies employing questionnaires is that only a few of the items have been used in valid and reliable strategy inventories of general language learning (e.g., the SILL developed by Oxford, 1990). Thus it is desirable to develop a new type of questionnaire that can bridge the gap between research-specific reading strategy questionnaires and the SILL.

\section{Research Questions}

The following research questions were investigated in this study through use of a new questionnaire designed to investigate awareness and use of EFL reading strategies and the relationship of strategies to English language proficiency: 
1. What factors are extracted through factor analysis indicating the degree of EFL learners' awareness of reading strategies?

2. How do two types of strategy awareness, use-awareness and effectawareness, interact with each other for better comprehension?

3. What is the relationship between the learners' level of strategy awareness and their English proficiency level?

\section{Method}

\section{Participants}

A convenience sample of 242 first- and second-year university EFL students studying at a private university in Japan completed the strategy questionnaire. There were 99 freshmen and 143 sophomores, all English majors. The percentages of males and females were $42.9 \%$ and $57.1 \%$ respectively and their ages ranged from 18 to 21 . Among the students who answered the questionnaire, 196 students also took an Institutional TOEIC administered at the time of the study. The mean of the two section tests (listening and reading) was $440(S D=96.3)$ and the scores ranged from 220 to 775 . Thus, the subjects' general English proficiency levels can be considered to be high beginning to high intermediate.

\section{Development of the Reading Strategy Questionnaire}

In developing a new questionnaire to probe learners' awareness concerning reading strategies, items used by Carrell (1989), the Tsudajuku study (1992), and Yamato (1997) comprised the core of the questionnaire. These items investigated particular reading strategies that were reported to affect comprehension (Hosenfeld, 1977; Brown, 1980; Baker \& Brown, 1984; Block, 1986). However, the items were regrouped, following the strategy classification of Oxford's SILL. ${ }^{4}$ In order to make up for a scarcity of items related to non-cognitive strategies, some items were replaced. The result was a total of 38 items in Japanese (see Table 2 for the English translation of the items). Broken down by SILL classification, the 38 items included eight metacognitive strategies, ${ }^{5} 14$ cognitive strategies, seven compensation strategies, four social strategies, three affective strategies, and two memory strategies. A seven-point Likert scale was provided for responses to items. The internal consistency of the instrument was .87 using Cronbach's coefficient alpha.

The questionnaire was designed to examine two types of learners' awareness of reading strategies. The first was the degree to which the learners perceive themselves to be using a given strategy (use-awareness), and the other was the degree to which they perceive a particular 
strategy to be effective (effect-awareness). The following explanation provides the rationale for inquiring about the two types of awareness in the same questionnaire.

In strategy training students sometimes report that they recognize that strategies are effective (effect awareness), but seldom report awareness of using strategies themselves (use awareness). Asking students about the two types of awareness thus makes it possible to observe if there are gaps between use-awareness and effect-awareness. Further, although a number of studies have reported the relationship between learners' awareness of their use of strategies (use-awareness) and their reading comprehension ability, few studies have compared the effects of both awareness types on reading comprehension. In this context, using a questionnaire that examines both types of strategy awareness can contribute to clarification of the relationship between strategy awareness and reading comprehension.

\section{Procedure}

The strategy questionnaire was administered in Japanese during regular class hours in a Survey of Linguistics class for the second-year students and in a Basic English Grammar class for the first-year students. Although the students were required to fill in their student number to match the questionnaire with the TOEIC score, they were informed that the results would be used only for research purposes and would not influence their grade for the course. The students were divided into three proficiency levels according to the TOEIC reading score. ${ }^{6}$ The upper group and lower group consisted of students whose TOEIC reading scores were $1 S D$ above and below the mean, respectively, and the middle group consisted of students whose scores were within $1 S D$ of the mean. The descriptive statistics of the learners' TOEIC reading scores are given in Table 1.

Table 1: TOEIC Reading Section Scores $(n=196)$

\begin{tabular}{llll}
\hline & & $M$ & $S D$ \\
\hline Upper & $n=26$ & 282.9 & 31.1 \\
Middle & $n=144$ & 191.8 & 29.2 \\
Lower & $n=26$ & 111.7 & 24.2 \\
\hline
\end{tabular}

$F(2,193)=229.2, p<.001$ 


\section{Statistical Procedures}

Factor Analysis: Data from the questionnaire were analyzed through Principal Component Factor Analysis. Three items were excluded: Items 20 and 27 for ceiling effects, and Item 38 for floor effects (Table 2). Factor analysis was conducted with the remaining 35 items and varimax rotation produced five factors. Nyikos \& Oxford (1993) explain that factor analysis is:

a technique that statistically links related elements (in this case, learning strategy items) that vary in synchrony with each other, thereby forming a cluster of items bound together by one common underlying factor...By using numerical values, factor analysis provides information helpful in formulating psychological and educational constructs in a relatively objective manner (p. 14).

Other Statistical Procedures: A one-way ANOVA was used to examine the relationships among the three proficiency levels, the subjects' TOEIC reading scores and their awareness of reading strategies. Paired $t$-tests and Fisher's Least Significant Difference (LSD) post hoc test were used to examine the gap between the learners' use of the two types of strategy awareness (effect-awareness and use-awareness) and their proficiency level. Regression analysis examining the relationship of the TOEIC reading score to the use-awareness scores and the gap scores was also conducted.

\section{Results}

\section{Factor Analysis of the Questionnaire Responses}

The pattern matrix for loadings greater than .40 as a criterion of factor salience appears in Table 3 . The cumulative variance of the five factors extracted was $45.6 \%$. This means that nearly half of the variability of the 35 items is explained by the five factors. ${ }^{7}$

As can be seen in Table 3, Factor 1 consisted of nine items with appreciable loadings. Most of the items, except for Items 12 and 6, are related to top-down processing, which helps learners to understand the gist of the text. Even the remaining two items seem to be more related to top-down processing than to bottom-up processing because neither is related to the specific details of a sentence. Therefore Factor 1 was called Top-down Processing Strategies.

Factor 2 consisted of eight items. Although these items cover a variety of content, all are related to strategies concerning extracurricular practices that may help learners enhance their reading comprehension. Therefore Factor 2 was called Extracurricular Practice Strategies. Factor 3 consisted of seven items, all of which seem related to bottom-up pro- 
Table 2: Mean Scores and Standard Deviations

for the Items and Their Strategy Types

\begin{tabular}{|c|c|c|c|c|}
\hline Iten & Statement & Type & $M$ & $S D$ \\
\hline \multicolumn{5}{|c|}{ When reading silently in English, } \\
\hline 1 & I anticipate what will come next in the text. & $\operatorname{Cog}$ & 4.02 & 1.37 \\
\hline 2 & I recognize the difference between main points and supporting details. & $\operatorname{cog}$ & 4.14 & 1.35 \\
\hline 3 & I relate new information to old information in the text. & $\operatorname{Cog}$ & 4.49 & 1.30 \\
\hline 4 & I question the significance or truthfulness of the content. & $\operatorname{cog}$ & 4.13 & 1.27 \\
\hline 5 & I use prior knowledge and experience to understand the content. & Meta & 4.93 & I. 42 \\
\hline 6 & I am aware of rhetorical structure of the text. & $\operatorname{Cog}$ & 3.58 & 1.34 \\
\hline 7 & I monitor whether or not I understand the part I am reading. & Meta & 4.26 & 1.37 \\
\hline 8 & I try to relax by thinking it's $\mathrm{OK}$ not to understand everything. & Affec & 4.11 & 1.41 \\
\hline 9 & I relax my posture not to feel tense. & Affec & 4.81 & 1.32 \\
\hline 10 & I read the text encouraging myself to believe reading is not difficult. & Affec & 3.47 & 1.55 \\
\hline 11 & If I am unable to understand something, I ask somebody for help. & Soc & 3.95 & 1.43 \\
\hline 12 & I discuss the difference between my interpretation and someone else's. & Soc & 3.53 & 1.50 \\
\hline 13 & I mentally sound out the words. & $\operatorname{cog}$ & 5.07 & 1.61 \\
\hline 14 & I understand the meaning of each word. & $\operatorname{cog}$ & 4.46 & 1.37 \\
\hline 15 & I get the overall meaning of the text. & $\operatorname{cog}$ & 5.37 & 0.94 \\
\hline 16 & If I am unable to understand something, I divide the sentence into chunks. & Comp & 4.75 & 1.30 \\
\hline 17 & etorical structure of text. & $\operatorname{cog}$ & 3.58 & 1.32 \\
\hline 18 & matical structure of each sentence. & $\operatorname{Cog}$ & 4.28 & 1.50 \\
\hline 19 & I relate the text to what I already know about the topic. & Meta & 4.57 & 1.33 \\
\hline 20 & I find $t$ & $\operatorname{cog}$ & 5.84 & 1.00 \\
\hline 21 & unfamiliar words from their affixes. & $\operatorname{cog}$ & 4.87 & 1.32 \\
\hline 22 & I understand the details of the content. & $\operatorname{cog}$ & 4.02 & 1.17 \\
\hline 23 & I grasp the idioms and phrase structures. & $\operatorname{Cog}$ & 4.90 & 1.14 \\
\hline \multicolumn{5}{|c|}{ When reading silently in English, if I don't understand something, } \\
\hline & I guess at the content using imagination. & Comp & 4.23 & 1.69 \\
\hline 25 & I reread the problematic part. & Comp & 5.68 & 1.25 \\
\hline 26 & I reread a point before the problematic part. & Comp & 5.57 & 1.21 \\
\hline 27 & for the meaning of unfamiliar words. & Comp & 5.85 & 1.20 \\
\hline 28 & I focus on the grar & Comp & 4.90 & 1.49 \\
\hline & I mentally sound out parts of the words. & Comp & 5.36 & 1.25 \\
\hline \multicolumn{5}{|c|}{ As for reading in English, every day out of classes, } \\
\hline & I build & Mem & 3.37 & 1.62 \\
\hline & I review grammar and vocabulary often. & Memo & 3.42 & 1.49 \\
\hline 32 & I read many texts about various topics. & Meta & 3.23 & 1.40 \\
\hline 33 & I look for opportunities to use English. & Meta & 4.52 & 1.46 \\
\hline 34 & I try to have good grammatical knowledge. & Meta & 4.15 & 1.50 \\
\hline 35 & I try to acquire correct pronunciation of words. & Meta & 4.92 & 1.56 \\
\hline 36 & I try to deepen my understanding of different cultures. & $\mathrm{Soc}$ & 4.46 & 1.52 \\
\hline 37 & I try to think logically. & Meta & 3.17 & 1.46 \\
\hline 38 & I make a study group with people with similar interests. & Soc & 1.88 & 1.30 \\
\hline
\end{tabular}

Note: The statement of each item is an English translation from the Japanese original.

Key for Strategy Type: $\operatorname{Cog}=$ Cognitive, Meta $=$ Metacognitive, Affec $=$ Affective, $\mathrm{Soc}=$ Social, Comp $=$ Compensation, Memo $=$ Memory 
Table 3: Factor Analysis Results

Item Factor Loading Commonalties

Factor 1 Factor 2 Factor 3 Factor 4 Factor 5

\begin{tabular}{|c|c|c|c|c|c|c|}
\hline 3 & 0.71 & & & & & 0.53 \\
\hline 4 & 0.66 & & & & & 0.47 \\
\hline 2 & 0.62 & & & & & 0.42 \\
\hline 1 & 0.59 & & & & & 0.47 \\
\hline 19 & 0.54 & & & & & 0.45 \\
\hline 12 & 0.50 & & & & & 0.35 \\
\hline 6 & 0.48 & & & & & 0.63 \\
\hline 5 & 0.46 & & & & & 0.36 \\
\hline 15 & 0.45 & & & & & 0.41 \\
\hline 31 & & 0.75 & & & & 0.67 \\
\hline 30 & & 0.74 & & & & 0.62 \\
\hline 33 & & 0.68 & & & & 0.55 \\
\hline 34 & & 0.67 & & & & 0.56 \\
\hline 35 & & 0.65 & & & & 0.48 \\
\hline 32 & & 0.64 & & & & 0.52 \\
\hline 36 & & 0.52 & & & & 0.45 \\
\hline 37 & & 0.45 & & & & 0.41 \\
\hline 7 & & & 0.73 & & & 0.55 \\
\hline 14 & & & 0.71 & & & 0.53 \\
\hline 18 & & & 0.64 & & & 0.53 \\
\hline 22 & & & 0.61 & & & 0.44 \\
\hline 23 & & & 0.55 & & & 0.41 \\
\hline 28 & & & 0.54 & & & 0.51 \\
\hline 16 & & & 0.46 & & & 0.41 \\
\hline 21 & & & & 0.58 & & 0.53 \\
\hline 29 & & & & 0.47 & & 0.37 \\
\hline 25 & & & & 0.45 & & 0.49 \\
\hline 24 & & & & 0.43 & & 0.28 \\
\hline 25 & & & & 0.40 & & 0.49 \\
\hline 11 & & & & -0.63 & & 0.48 \\
\hline 9 & & & & & 0.53 & 0.34 \\
\hline 8 & & & & & 0.41 & 0.33 \\
\hline \multirow{2}{*}{\multicolumn{2}{|c|}{$\begin{array}{l}\text { Eigenvalue } 4.11 \\
\text { Percent of } 11.73 \\
\text { Explained Variance }\end{array}$}} & 4.03 & 3.63 & 2.25 & 1.93 & \\
\hline & & 11.53 & 10.34 & 6.44 & 5.50 & \\
\hline
\end{tabular}

Note: Only items with loadings equal to or over 0.40 are indicated in the table. 
cessing. Among these seven items, Items 18, 23, 28, and 16 concern sentence-level grammar and parsing. Therefore, Factor 3 was called Grammar-Oriented Bottom-up Processing Strategies. Factor 4 consisted of six items. The first two items, with the highest loadings, are strategies to figure out word meanings, that is, bottom-up strategies. Items 26 and 24, which focus on local points of the text, are also related to bottom-up processing. Although the remaining two items are not directly concerned with bottom-up processing, Factor 4 was called Vocabulary-Oriented Bottom-up Processing Strategies because the majority of the items with high loadings are related to bottom-up processing and word meanings. Finally, Factor 5 includes two items, both of which are strategies which learners can use to help them relax and lower the affective filter while reading. Therefore this factor was termed Relaxation Strategies.

The Gap between the Two Types of Strategy Awareness

The following calculations were performed to examine whether gaps existed between the students' reported use-awareness and effect-awareness. To determine use-awareness, each student's answers for each set of items constituting the five factors were tabulated to yield mean scores.

Figure 1: Gap between Two Awareness Types

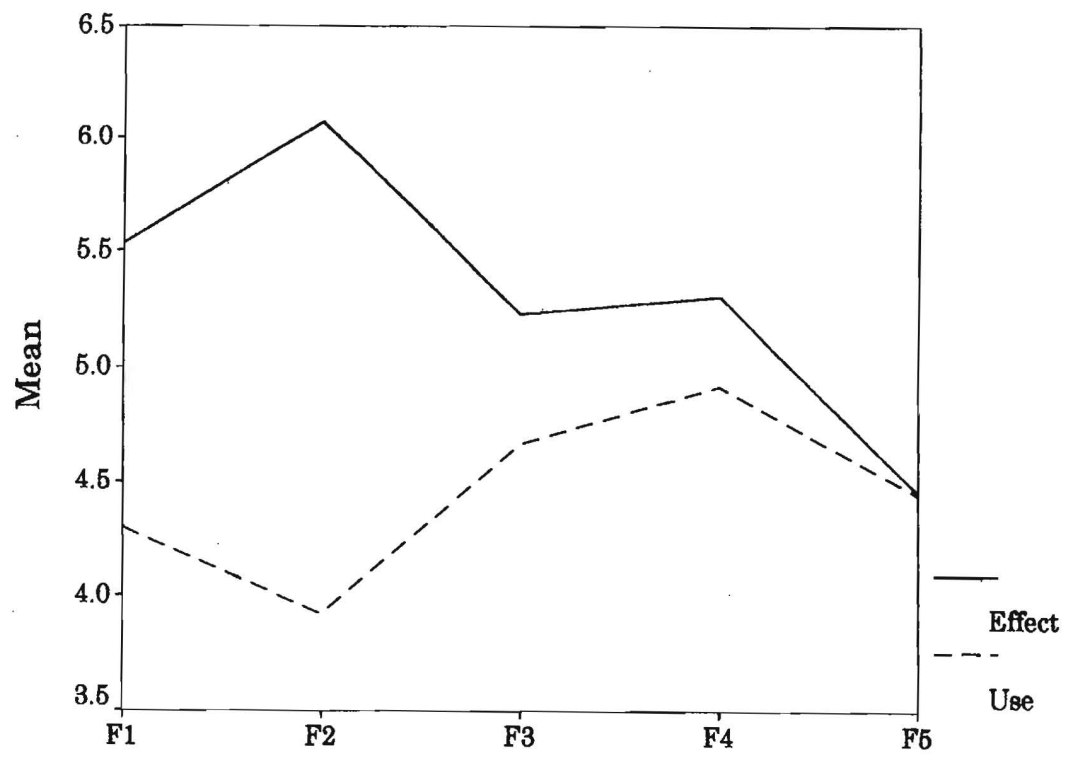


The mean scores reflect the degree to which the students perceive themselves to be using each set of strategies contained in the five factors. The same procedure was done for the students' effect-awareness. Figure 1 and Table 4 show the difference, or gap, between the students' reported strategy use-awareness and their strategy effect-awareness.

Table 4: Matched $t$-tests for Gaps between Two Awareness Types

$$
(n=196)
$$

\begin{tabular}{|c|c|c|c|c|c|c|}
\hline Pair & Awareness Type & $M$ & $S D$ & $t$-value & $d f$ & $p$ \\
\hline \multirow[t]{2}{*}{ Factor 1} & Effect-awareness & 5.54 & 0.61 & 19.29 & 195 & $*$ \\
\hline & Use-awareness & 4.37 & 0.82 & & & \\
\hline \multirow[t]{2}{*}{ Factor 2} & Effect-awareness & 6.05 & 0.65 & 27.66 & 195 & * \\
\hline & Use-awareness & 3.95 & 0.95 & & & \\
\hline \multirow[t]{2}{*}{ Factor 3} & Effect-awareness & 5.24 & 0.82 & 9.79 & 195 & * \\
\hline & Use-awareness & 4.59 & 0.85 & & & \\
\hline \multirow[t]{2}{*}{ Factor 4} & Effect-awareness & 5.30 & 0.81 & 5.92 & 195 & * \\
\hline & Use-awareness & 4.92 & 1.03 & & & \\
\hline \multirow[t]{2}{*}{ Factor 5} & Effect-awareness & 4.57 & 1.06 & 0.03 & 195 & n.s. \\
\hline & Use-awareness & 4.56 & 1.12 & & & \\
\hline
\end{tabular}

${ }^{*} p<.001$

As shown in Figure 1, gaps exist between effect-awareness and useawareness. The results of a paired $t$-test presented in Table 4 show that, except for Factor 5, statistically significant differences exist between students' effect-awareness and use-awareness according to the factors. As anticipated, the score of effect-awareness is generally higher than that of use-awareness. This suggests that the students in this study are not using strategies as much as they may want to, although they recognize that strategies are effective. However, the scores of not only effect-awareness but also use-awareness are above the midpoint of the seven-point scales for most of the factors. ${ }^{8}$ One interpretation of this result suggests that students consider themselves to be using reading strategies fairly frequently.

The magnitude of the differences between the reported levels of the two kinds of awareness varied depending on factor types. The largest gap was found with Factor 2, Extracurricular Practice Strategies. Factor 1 (Top-Down Strategies) also showed a fairly large gap. On the other hand, Factors 3 and 4 , both of which are strategies for bottom-up processing, showed relatively small gaps between the students' reported effect-awareness and their use-awareness. Almost no gap existed between the two awareness types for Factor 5 (Relaxing Strategies). 
As far as effect-awareness is concerned, as shown in Table 5, the scores of Factors 1 and 2 are significantly higher than those of Factors 3, 4 , and 5. This means that the learners perceive strategies related to topdown processing or extracurricular practices to be more effective than those related to bottom-up processing or relaxation. As for use-awareness, however, the scores of Factors 1 and 2 were lower than those of Factors 3, 4, and 5, as shown in Table 6. This suggests that the learners perceive themselves to be $u$ sing bottom-up processing or relaxation strategies more frequently than top-down processing or extracurricular practice strategies. Taken together, these somewhat contradictory results suggest that the students use strategies they perceived as less effective more frequently than they use strategies they perceived to be more effective.

Table 5: Matched $t$-tests for Effect-Awareness Score $(n=196)$

\begin{tabular}{llllrrr}
\hline \multicolumn{2}{c}{ Pair } & Mean & $S D$ & $t$-value & $d f$ & $p$ \\
\hline Pair 1 & F1 \& F3 & 0.299 & 0.72 & 5.95 & 195 & $* *$ \\
Pair 2 & F1 \& F4 & 0.237 & 0.81 & 3.86 & 195 & $* *$ \\
Pair 3 & F1 \& F5 & 0.974 & 1.10 & 13.86 & 195 & $* *$ \\
Pair 4 & F2 \& F3 & 0.813 & 0.78 & 15.35 & 195 & $* *$ \\
Pair 5 & F2 \& F4 & 0.754 & 0.94 & 11.51 & 195 & $* *$ \\
Pair 6 & F2 \& F5 & 1.483 & 1.21 & 19.02 & 195 & $* *$ \\
\hline
\end{tabular}

${ }^{* *} p<.001$

Table 6: Matched $t$-tests for Use-Awareness Score $(n=196)$

\begin{tabular}{|c|c|c|c|c|c|c|}
\hline \multicolumn{2}{|c|}{ Pair } & Mean & $S D$ & $t$-value & $d f$ & $p$ \\
\hline Pair 1 & $F 1 \& F 3$ & -0.234 & 0.93 & -5.73 & 195 & $* *$ \\
\hline Pair 2 & $\mathrm{~F} 1 \& \mathrm{~F} 4$ & -0.552 & 0.99 & -9.07 & 195 & $* *$ \\
\hline Pair 3 & F1 \& F5 & -0.186 & 1.28 & -1.73 & 195 & + \\
\hline Pair 4 & F2 \& F3 & -0.643 & 1.05 & -10.25 & 195 & $* *$ \\
\hline Pair 5 & $F 2 \& F 4$ & -0.972 & 1.22 & -11.78 & 195 & $* *$ \\
\hline Pair 6 & F2 \& F5 & -0.608 & 1.43 & -5.33 & 195 & $* *$ \\
\hline
\end{tabular}

** $p<.001$

$+p<.1$ 


\section{Strategy Awareness and TOEIC Scores}

In this section the relationship between the learners' two types of strategy awareness and their proficiency levels, as measured by their TOEIC reading section scores, will be investigated. First, the relationship between the learners' effect-awareness score and their TOEIC reading score is examined according to their proficiency group (Upper, Middle, or Lower)

Figure 2 suggests that the three proficiency groups have very similar patterns of effect-awareness of reading strategies. For all five factors, there were no statistically significant differences found among the three levels of proficiency. This is interesting because it has been reported elsewhere that learners' awareness of reading strategies is positively related to their proficiency (e.g., Barnett, 1988; Carrell, 1989; Tsudajuku, 1992; Yamato, 1997; Hirano, 1998). The difference between those studies and the present study is that two types of metacognitive awareness (effect-awareness and use-awareness) are used in this study. The con-

Figure 2: Effect-Awareness by TOEIC Reading

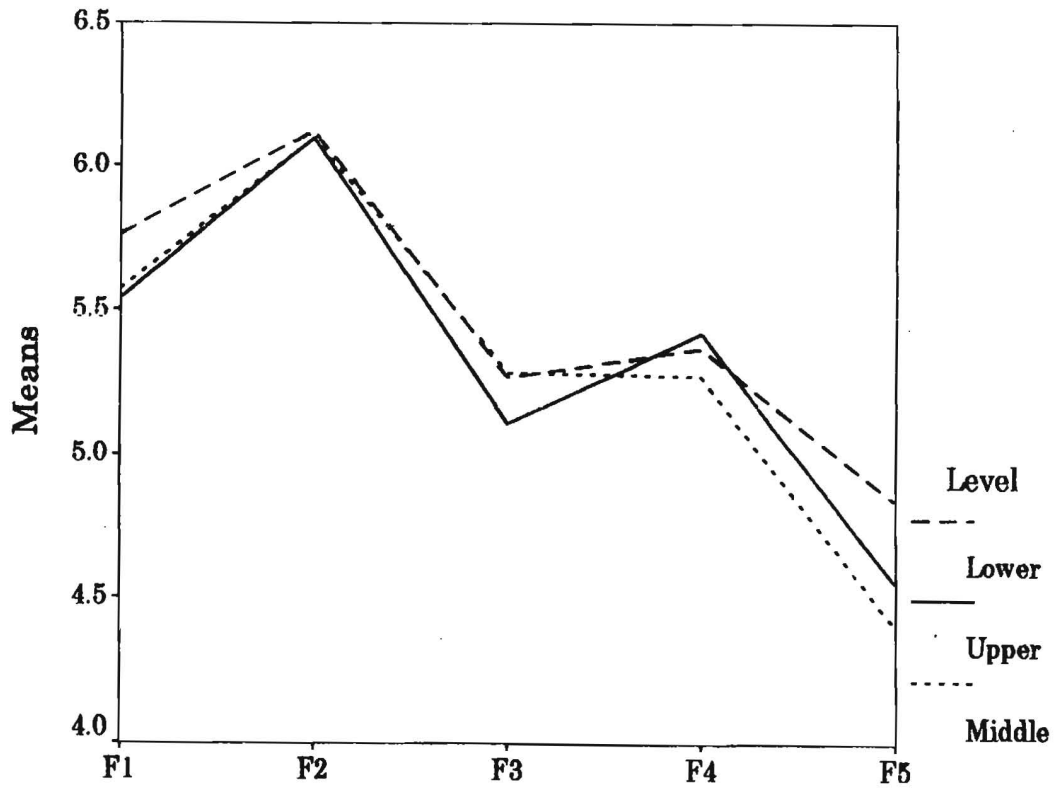

FACTOR 
cept of use-awareness is almost identical to that of metacognitive awareness in other studies, whereas the concept of effect-awareness is unique to this study. Therefore all that the data have suggested is that mere knowledge of effective reading strategies will not necessarily lead to enhanced reading comprehension.

Two questions emerge from the results reported so far. First, do all learners, regardless of their proficiency levels, have the same pattern of awareness with respect to the effectiveness of reading strategies? Second, even if knowledge of effective strategies has not been shown to directly improve reading comprehension, is such knowledge therefore useless? These points will be discussed below.

As for the relationship between the scores of use-awareness and the TOEIC reading section scores, Figure 3 shows that the relationship of the use-awareness scores to proficiency is slightly different from that of the effect-awareness scores. A one-way ANOVA yielded a noticeable tendency for Factors 3 and $4 .^{9}$ As shown in Table 7, both upper and

\section{Figure 3: Use-Awareness by TOEIC Reading}

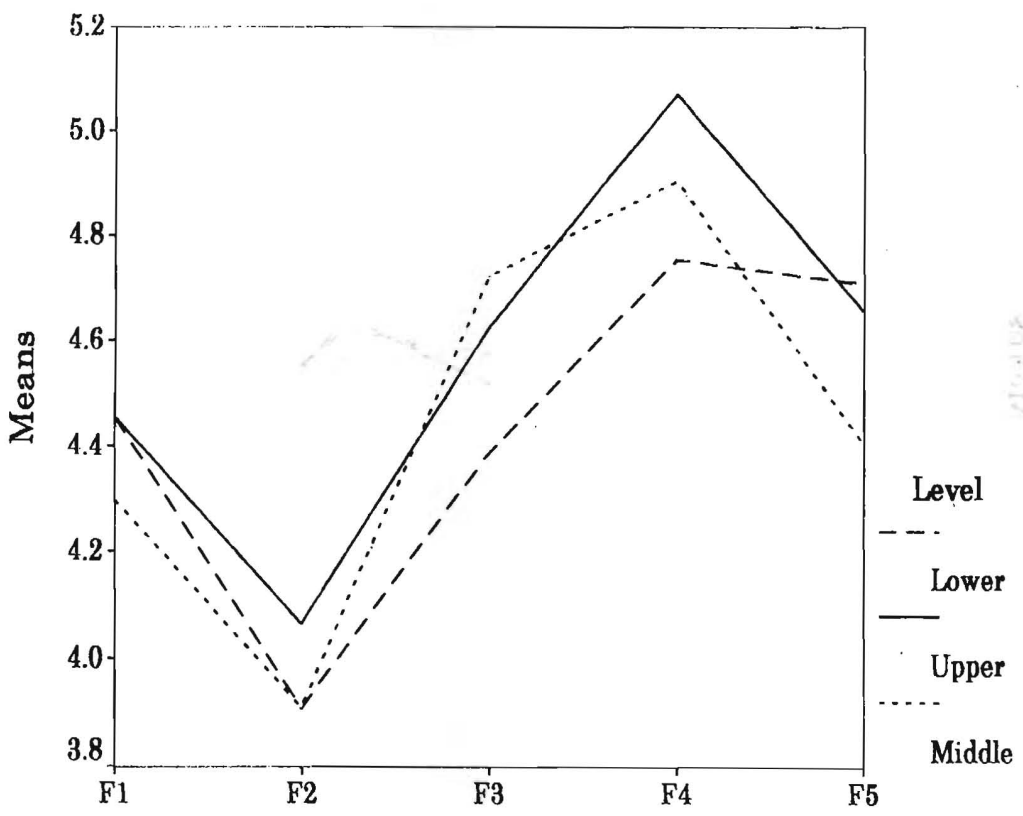

FACTOR 
middle proficiency level students reported using Factor 3 strategies more frequently than students in the lower proficiency level group, and the upper group students also reported using Factor 4 strategies more frequently than did the lower group. However, there was almost no difference in the learners' use-awareness among the three groups for Factor 1 (Top-Down Strategies). These results are inconsistent with the findings of prior studies reporting that good readers tend to use top-down strategies whereas poor readers tend to use bottom-up strategies (e.g., Barnett, 1988; Carrell, 1989; Tsudajuku, 1992; Yamato, 1997).

Table 7: Results of ANOVA and LSD on Use-Awareness Scores of Three Proficiency Levels

\begin{tabular}{|c|c|c|c|c|c|c|c|c|c|}
\hline & \multicolumn{2}{|c|}{$\begin{array}{l}\text { Upper } \\
(n=26)\end{array}$} & \multicolumn{2}{|c|}{$\begin{array}{l}\text { Middle } \\
(n=144) \\
\end{array}$} & \multicolumn{2}{|c|}{$\begin{array}{l}\text { Lower } \\
(n=26) \\
\end{array}$} & \multirow[b]{2}{*}{$F$} & \multirow[b]{2}{*}{$p$} & \multirow{2}{*}{$\begin{array}{l}\text { Post hoc } \\
L S D\end{array}$} \\
\hline & $M$ & $(S D)$ & $M$ & $(S D)$ & $M$ & $(S D$ & & & \\
\hline$\overline{\text { Factor } 1}$ & 4.43 & 0.81 & 4.26 & 0.84 & 4.42 & 0.69 & 1.04 & & \\
\hline Factor 2 & 4.09 & 1.07 & 3.88 & 0.98 & 3.87 & 0.83 & 0.42 & n.s. & \\
\hline Factor 3 & 4.67 & 0.62 & 4.75 & 0.89 & 4.34 & 0.69 & 2.69 & + & $\mathrm{U}=\mathrm{M}>\mathrm{L}$ \\
\hline Factor 4 & 5.11 & 0.61 & 4.92 & 0.77 & 4.73 & 0.72 & 2.23 & + & $\mathrm{U}>\mathrm{L}$ \\
\hline Factor 5 & 4.63 & 1.05 & 4.39 & 1.09 & 4.66 & 1.26 & 1.93 & n.s. & \\
\hline
\end{tabular}

Note: $L S D=$ Fisher's least significant difference test, which is equivalent to multiple individual $t$ tests between all pairs of groups.

$+p<.01$

One reason for these results may be that the TOEIC reading section consists of three parts: vocabulary, grammar, and reading passages, whereas previous studies were based only on reading measures. Furthermore, many questions in the reading passages are fact-based questions that do not necessarily require logical inferences based on top-down processing. The structure of the TOEIC reading section could have made the role of top-down strategies less important, thereby making it easier for learners who prefer bottom-up strategies to appear more proficient than they actually are. Another possible reason is that the lower group students have less grammatical competence so they might rely on topdown strategies in order to compensate for this lack. Such behavior may explained by an interactive-compensatory model proposed by Stanovich (1980). On the other hand, the middle group students may be slightly more confident in their grammatical competence and are willing to use that resource in reading. This might explain why, in Figure 3, the middle group students report using some bottom-up strategies as frequently as 
upper group students. As for the upper group students, perhaps they still have not reached the stage in which their grammatical competence makes decoding processes automatic. Therefore they may not be able to allot enough cognitive capacity for top-down processing to be significantly different from the other groups.

Finally, the relationship between the differences in the two awareness types and the TOEIC reading section scores is examined. As shown in Figure 4, the gaps between the two awareness types appeared to decrease as proficiency level increased for all factors, but it is only for Factor 3 that a Fisher LSD post hoc test yielded a noticeable tendency $(\mathrm{U}>\mathrm{L}, p<.1)$.

Comparing this with the results for effect-awareness, for which there were no significant differences among the three proficiency levels, and with use-awareness, for which there were noticeable tendencies for two factors, the gaps between the two awareness types might be less related

\section{Figure 4: Gap between the Two Awareness Types}

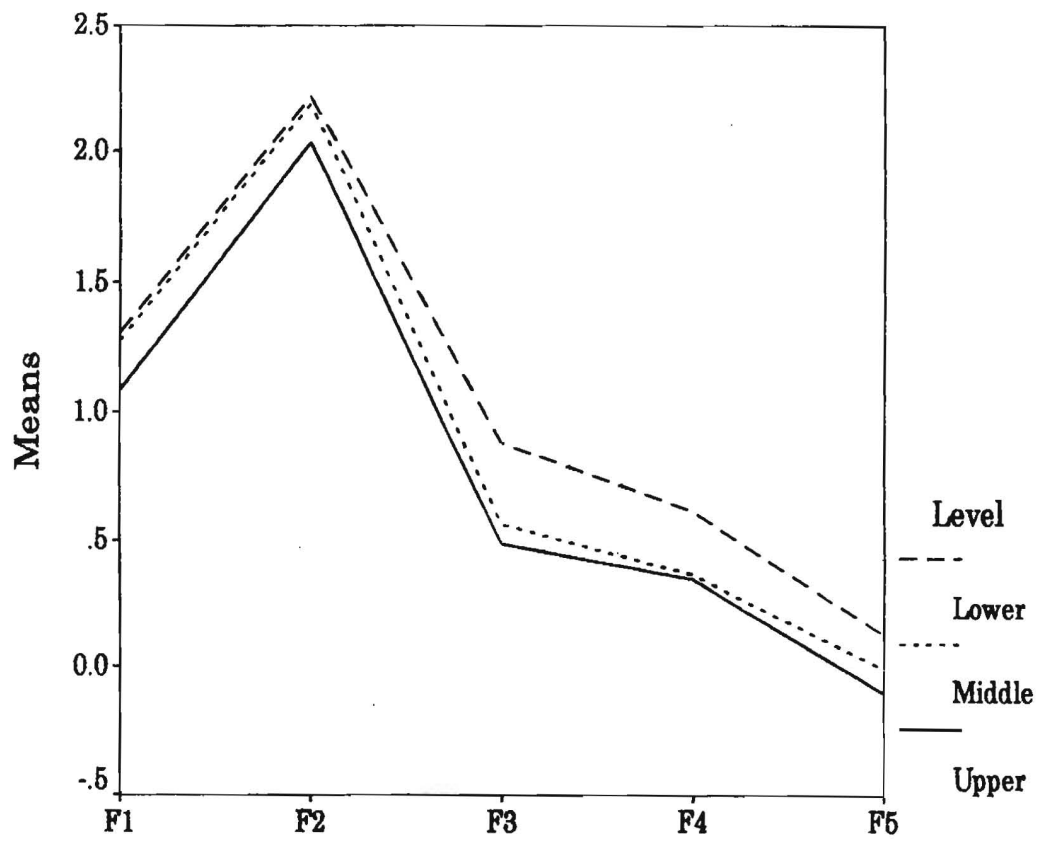


to TOEIC reading scores than use-awareness by itself, but are more related to the scores than effect-awareness alone.

\section{Discussion}

\section{The Gap Between Effect-Awareness and Use-Awareness}

It has been shown that there is a difference between students' reported awareness of the effectiveness of different strategies (effect-awareness) and their reports of the strategies they are aware of using (use-awareness). Effect-awareness scores (meaning that students knew about strategies) were generally higher than use-awareness scores (meaning that they reported using strategies). This result suggests that learners' knowledge about which strategies are good or effective for reading (declarative knowledge) precedes their knowledge about how to use them (procedural knowledge). This interpretation is in line with the suggestions of Baker and Brown (1984).

Another finding is that the magnitude of the gaps between the two awareness types varies depending on the factor type. Although the students consider top-down strategies to be more useful for effective reading than bottom-up strategies, they report using bottom-up strategies and relaxation strategies more frequently than top-down strategies or extracurricular practice strategies. This suggests two possibilities. First, the students might not possess sufficient procedural knowledge of topdown processing strategies to use them, and second, they may perceive top-down strategies as superior to bottom-up strategies. Although this understanding of reading strategies is considered typical of most learners, it is contested by the interactive model proposed by Eskey (1988) and others (e.g., McClelland \& Rumelhart, 1981; Stanovich, 1980; Perfetti, 1985), a model which, "does not presuppose the primacy of top-down processing skills-the gradual replacing of painful word-by-word decoding with educated guessing based on minimal visual cues" (Eskey, 1988, p. 94). Taken together, these facts indicate the need for teachers to provide learners with more opportunities to learn how to use top-down strategies. At the same time, learners also need to learn that top-down strategies are not necessarily better than bottom-up, relaxation, or extracurricular practice strategies.

\section{The Relationship Between Strategy Awareness and Proficiency Level}

As for the relationship between strategy awareness and proficiency level, results were inconclusive, with no clear statistical differences among the three proficiency levels. It was particularly surprising that there was 
no evident significant difference among the three proficiency levels for use-awareness scores.

There are two possible explanations for this unexpected result. The first concerns the subjects of this study. Compared to the subjects used by Green and Oxford (1995), a study reporting significant differences in the strategy use-awareness among three proficiency levels as determined by the scores of the English as a Second Language Achievement Test (ESLAT),${ }^{10}$ the range of the students' proficiency scores in this study was quite limited. In Green and Oxford's study, the three groups, labeled Prebasic, Basic, and Intermediate, covered a wide range of proficiency. The Prebasic level, with scores of 200 (the lowest possible) to 419, was regarded as low beginner. The Basic level, with scores of 420 to 570 , was regarded as high beginner to low intermediate, and the Intermediate level, with scores of 571 to the highest possible score of 800 , was regarded as high intermediate to truly advanced. The main differences in strategy use were found between the Prebasic level and the other two groups. Green and Oxford comment, "Had we only included Basic and Intermediate students in our sample, our results would have been much weaker" (1995, p. 286). Since most of the subjects in the present study have limited English proficiency and would therefore probably belong to the Basic group described by Green and Oxford, it is understandable that the data did not yield many significant relationships between strategy use-awareness and proficiency level.

However, this explanation is not sufficient considering the results of other studies (e.g., Tsudajuku, 1992; Yamato, 1997; Edasawa et al., 1998) which also used questionnaire methodology to investigate Japanese EFL. learners with a limited range of proficiency levels, yet found significant differences in strategy use-awareness among the levels. The crucial difference between these previous studies of Japanese EFL learners and the present study is that only English majors participated in this research, whereas students from various non-English majors participated in the other studies. It is possible that, regardless of their proficiency level, English majors may be more highly motivated to study English than other students, and are more concerned about language learning strategies than students studying English as a course requirement or for examinations. Thus it can be suggested that the limited range of proficiency and the homogeneous nature of the subjects contributed to the inconclusive results reported here.

A second explanation for the lack of significant differences among the three groups is related to the data analysis procedure. As reported, tabula- 
tions were conducted only for awareness scores for each factor as a whole, ignoring differences among the scores for each strategy. Therefore there is a possibility that statistically significant differences might appear if specific strategies within each factor are examined. To examine this possibility, regression analysis of the TOEIC reading score with use-awareness scores and gap scores was conducted. Tables 8 and 9 show the results.

Table 8: Regression Analysis of Use-Awareness Score and TOEIC Reading Score

\begin{tabular}{lcccrcc}
\hline Item & Factor Type & $B$ & Beta & $R^{2}$ & t-value & $p$ \\
\hline 1 & F 1 & 12.41 & 0.34 & 0.06 & 4.32 & $* *$ \\
34 & F 2 & -7.13 & -0.20 & 0.09 & -2.51 & $*$ \\
18 & F 3 & 6.36 & 0.18 & 0.11 & 2.40 & $*$ \\
19 & F 1 & -6.3 & -0.17 & 0.14 & -2.19 & $*$ \\
Constant & & 173.02 & & 26.77 & $* *$ & \\
\hline
\end{tabular}

${ }^{*} p<.05$

$* * p<.01$

Table 9: Regression Analysis of the Gap Score and TOEIC Reading Score

\begin{tabular}{lcrrrrr}
\hline Item & Factor Type & $B$ & Beta & $R^{2}$ & $t$-value & $\mathrm{p}$ \\
\hline 22 & F 3 & -7.56 & -0.20 & 0.05 & -2.41 & $*$ \\
5 & F 1 & -6.98 & 0.19 & 0.08 & -2.24 & $*$ \\
1 & F 1 & -11.92 & -0.34 & 0.11 & -3.61 & $* *$ \\
2 & F 1 & 8.43 & -0.24 & 0.13 & 2.63 & $* *$ \\
11 & NA & 5.99 & 0.18 & 0.16 & 2.38 & $*$ \\
30 & F 2 & -6.89 & -0.25 & 0.19 & -3.01 & $* *$ \\
34 & F 3 & 6.88 & 0.24 & 0.22 & 2.68 & $* *$ \\
Constant & & 200.67 & & & 26.77 & $* *$ \\
\hline
\end{tabular}

${ }^{*} p<.05$

${ }^{* *} p<.01$

As shown, a combination of use-awareness scores and gap scores is able to explain some variability of TOEIC reading section scores. The explained percentage of the variability- $14 \%$ by the use-awareness scores and $22 \%$ by the gap scores-suggests that, compared to the use-awareness scores, the gap scores of specific strategies are more related to the 
TOEIC reading section scores. This indicates that, even if learners think they use a certain strategy, such use may not necessarily lead to improvement in reading comprehension if the user is not fully convinced of the strategy's effectiveness. If this is the case, the gap scores for specific strategies might reflect the relationship between learners' two types of strategy awareness and their reading proficiency more accurately than the use-awareness scores alone.

The results of Tables 8 and 9 also show that more Factor 1 strategies are related to TOEIC reading scores than the strategies of the other factors. However, looking at the direction of the regression, it is difficult to determine which set of reading strategies is more related to reading comprehension because not all strategies belonging to the same factor behave in the same way. For example, in Table 8, Item 1 of Factor 1 (Anticipate what will come next in the text) shows a positive relationship with proficiency scores, whereas Item 19 (Relate the text to what I already know about the topic) shows a negative relationship. No conclusive explanation can be given at this stage, but it is possible that the excessive use of top-down strategies may lead the user to misunderstand the text. Comparing the two items, Item 19 seems to suggest that the user is using top-down strategies without appropriate decoding processes. As for the other two items in Table 8 related to grammatical competence, Item 18 (Grasp the grammatical structure of each sentence), which is positively related to proficiency scores, is a strategy used in the reading process, whereas Item 34 (Try to have good grammatical knowledge), with a negative relationship, is a strategy used independently of reading. Whereas the exercise of decoding skills in reading is effective, if the learner only practices grammar outside of English classes, and does not read as well, grammar practice alone will not promote reading gains. A similar interpretation seems to hold for the results in Table 9.11

\section{Usefulness of Effect-Awareness}

Several causes for the general lack of significant differences in learner awareness among the three proficiency levels have been suggested. However, one more question also needs to be briefly addressed: Is just knowing which strategies are effective (declarative knowledge) useless? In a review of studies related to the role of attention in second language acquisition, Tomlin and Villa (1994) suggest that awareness may indirectly lead to learning. They argue that, "awareness may augment alertness and orientation," both of which "may separately or together enhance the chances for detection to occur," which is "necessary for acquisition" (p. 197). Schmidt (1995) seems to take a stronger position regarding the role of awareness in learning, arguing that "awareness at the point of learning is required for all 
learning" (p. 27). Thus, it appears that awareness plays a role in language learning, in an indirect or a direct manner, so effect-awareness is useful.

However, in order to further investigate the complicated relationship between reading comprehension and the types of learners' awareness of reading strategies, future research using diverse subjects with a wide range of proficiency levels is necessary and this research should also be informed by findings from cognitive psychology regarding awareness.

\section{Integration of the Reading Strategy Inventory with the Interactive Reading Model}

In this study, five factors concerning reading strategies were extracted from a 38-item questionnaire by factor analysis. According to Oxford (1990, 1992), factor analysis provides evidence that the strategies classified in the SILL will work, particularly when they are combined with each other. In this context, it should be recalled that in the present study strategies belonging to different categories of the SILL appeared as items in factors characterized as Top-Down Strategies and Bottom-Up Strategies. This result is of some importance because it provides the possibility of integrating the SILL with an "interactive reading model" that "posits a constant interaction between bottom-up and top-down processing in reading, each source of information contributing to a comprehensive reconstruction of the meaning of the text" (Eskey, 1988, p. 94). Since this interactive model has been regarded as a powerful model explaining the reading process, it is possible that the strategies classified in the SILL will work better or will be easier to acquire if they are presented in concert with the interactive reading model. The following section makes specific pedagogical recommendations for doing so.

\section{Conclusion}

The results of the present study have relevance for strategy instruction. The first implication derives from the fact that the students perceive top-down strategies to be superior to bottom-up strategies, and yet they seem to be less aware of how to use top-down strategies than how to use bottom-up strategies. In other words, top-down strategies are seen as effective but difficult to use, thus making learners less willing to use them.

Regarding this restricted use of top-down strategies, some researchers (e.g., Clark, 1980; Lee \& Schallert, 1997) have suggested that there is a proficiency "threshold" for successful employment of top-down strategies. However, such a "threshold hypothesis" should not be misinterpreted as a call for a return to traditional grammar-oriented lan- 
guage teaching. In fact, many traditionally-instructed learners tend to think that the intellectual guessing characteristic of top-down processing is something that they can acquire only after a struggle to develop high-level proficiency and is not a skill to be used at more basic levels. While it is true that automatic decoding skills enable fluent readers to employ various higher-level top-down strategies, this does not mean that any fixed level of grammatical competence ensures the "automaticity" of the decoding process. In other words, the "threshold" level varies depending on the difficulty of a given task. In this context, the use of top-down strategies should be encouraged even at the early stages of language learning. By starting strategy instruction with emphasis on how to use top-down strategies-even for beginning students with neither solid grammatical competence nor a large vocabulary-the students will be able to understand the nature of reading and can develop an appropriate awareness of reading strategies as they progress as readers.

This kind of strategy training will eventually lead learners to the state in which they can choose a strategy appropriate for a given task from their inventory of both top-down and bottom-up strategies and can use the strategies interactively.

The second implication derives from the result that reading strategies classified into different categories of the SILL converged into five factors in the data reported here, three of which fit in with an interactive model of reading. This suggests that EFL learners unconsciously rely on the most viable information-processing model for a particular target language skill. If this is the case, it is important to design strategy instruction with due consideration for an appropriate learning model of the target skill.

The five metacognitive elements in strategy instruction given by Winograd and Hare (1988) are useful to consider when attempting strategy training. As cited in Carrell (1998), the five elements are: (1) what the strategy is; (2) why the strategy should be learned; (3) how to use the strategy; (4) when and where the strategy should be used; and (5) how to evaluate use of the strategy. According to Carrell (1998), "successful strategy training can involve some but not necessarily all of the desirable elements of metacognitive strategy training" (p.11).

To introduce metacognitive elements in strategy training in the EFL classroom in Japan, students should receive an explanation of the interactive reading model and receive instruction on "when and where the strategy should be used." In cases where explanation is not enough, it might be helpful to have learners try what the instructor considers to be an unsuitable strategy as well as a correct one so that they can 
appreciate the importance of using strategies selectively. It is possible that students can learn from negative evidence as much as from positive evidence in their strategy training. ${ }^{12}$

Whatever effective strategy training is developed, it is not the training itself but the teacher, together with the learner, who determines its success. Teachers with the dual responsibilities of instructor and researcher will need to make more effort to link research findings with classroom teaching to create effective programs for strategy use.

\section{Acknowledgements}

This article is based on a presentation given at JALT98 in Omiya. The author would like to thank the two anonymous reviewers for their suggestions and valuable comments on earlier versions of this paper.

Ryusuke Yamato is an associate professor in the Department of Foreign Languages at Hokuriku University, Kanazawa. His research interests include language learning strategies and the acquisition of tense and aspect.

\section{Notes}

1. The term "awareness" in this study is similar to the definition given in Tomlin and Villa (1994) since it refers to the learner's subjective experience of content and external stimulus. Therefore the term is different from "consciousness," which has multiple associate meanings, as explained in Schmidt (1990).

2. See Oxford (1990, pp. 18-21) and O'Malley and Chamot (1990, p. 46) for a detailed explanation of their subcategorization systems.

3. In her study and in the other two that used a strategy questionnaire (Tsudajuku, 1992; Yamato, 1997), the questionnaire was administered in the learners' native language in order to avoid having the level of language proficiency in the target language affect the results.

4. It was not easy to classify strategies according to the SILL categories, because a strategy can be labeled differently depending on the way it is interpreted. For example, Item 30 (I build up vocabulary by using a wordbook) was categorized as a memory strategy, but it can also be considered a cognitive strategy if systematic memorization is emphasized.

5. Oxford (1990) claims that some strategies affect language learning directly and others indirectly. In this context, although Items 33 to 38 seem irrelevant to reading, it was considered necessary to include them in the questionnaire as metacognitive strategies for planning in order to examine whether or not the learners' awareness toward indirect strategies affects comprehension.

6. The point at issue here is the relationship between the learners' awareness of reading strategies and their reading comprehension. Therefore the reading section scores are considered to be appropriate in determining the students' proficiency level. 
7. The preferred value for the variability explained by extracted factors is above $50 \%$, but the value in this study is considered acceptable in comparison with other reading strategy studies employing factor analysis. In Hirano (1998), the value was $40.6 \%$ by five factors, in Green and Oxford (1995), the value was $51.6 \%$ by nine factors, and the value is not given either in Nyikos and Oxford (1993) or in Tsudajuku (1992).

8. The only exception is the use-awareness score of Factor 2 , but its value is as high as 3.95 .

9. Although the usual significance value for applied linguistics research is $p<$ .05 , the author judged that probability values slightly above the boundary should not be disregarded. Therefore, this value is retained in the study. However, there is a strong necessity to replicate the research presented here.

10. ESLAT is a general proficiency test administered only in Puerto Rico and its validity and reliability are well-established. See Green and Oxford (1995) for a detailed explanation.

11. In interpreting Tables 8 and 9 , it should be noted that negative values reflect a positive relationship with reading comprehension because the smaller the gap, the higher the proficiency level.

12. Practice providing negative evidence is more suitable for intermediate learners who possess a fairly good knowledge of reading strategies but have difficulty using them appropriately. Beginning learners should practice good strategies first.

\section{References}

Baker, L., \& Brown, A. L. (1984). Metacognitive skills and reading. In D. Pearson. (Ed.), Handbook of reading research (pp. 353-359). New York: Longman.

Barnett, M. A. (1988). Reading through context: How real and perceived strategy use affects L2 comprehension. Modern Language Journal, 72 (2), 150162.

Block, E. (1986). The comprehension strategies of second language readers. TESOL Quarterly, 20 (3), 463-494.

Brown, A. L. (1980). Metacognitive development and reading. In R. Spiro, B. Bruce \& W. Brewer (Eds.), Theoretical issues in reading comprehension (pp. 453-481). Hillsdale, NJ: Erlbaum.

Carrell, P. (1989). Metacognitive awareness and second language reading. Modern Language Journal, 73 (2), 121-34.

Carrell, P. (1998). Can reading strategies be successfully taught? The Language Teacher, 22 (3), 7-14.

Clark, M. A. (1980). The short-circuit hypothesis of ESL reading-or when language competence interferes with reading performance. Modern Language Journal, 64, 203-209.

Edasawa, Y., Kadota, S., Nakanishi, Y., Takashima, J., Wakamoto, N., \& Yoshimura, M. (1998). A survey of task-based reading strategies by Japanese learners of English. Paper presented at the JACET 37th Annual Convention. 
Eskey, D. E. (1988). Holding the bottom: an interactive approach to the language problems of second language readers. In P. Carrell, J. Devine, \& D. Eskey (Eds.), Interactive approaches to second language reading (pp. 93100). Cambridge: Cambridge University Press.

Green, J., M., \& Oxford, R. (1995). A closer look at learning strategies, L2 proficiency, and gender. TESOL Quarterly, 29 (2), 261-297.

Hirano, K. (1998). Japanese students' metacognitive awareness and EFL reading recall: Comparisons among high school, undergraduate, and graduate students. JACET Bulletin, 29, 33-50.

Hosenfeld, C. (1977). A preliminary investigation of the reading strategies of successful and nonsuccessful second language learners. System, 5, 110-123.

Lee, J., \& Schallert, D. L. (1997). The relative contribution of L2 language proficiency and L1 reading ability to L2 reading performance: A test of the threshold hypothesis in an EFL context. TESOL Quarterly, 31 (4), 713-739.

McClelland, J., \& Rumelhart, D. (1981). An interactive activation model of the effect of context in perception. Psychological Review, 88, 375-407.

Nyikos, M., \& Oxford, R. L. (1993). A factor analytic study of language learning strategy use: Interpretations from information-processing theory and social psychology. Modern Language Journal, 77, 11-22.

O'Malley, J., \& Chamot, A. (1990). Learning strategies in second language acquisition. Cambridge: Cambridge University Press.

Oxford, R. (1990). Language learning strategies: What every teacher should know. Boston, MA: Heinle \& Heinle.

Oxford, R. L. (1992). The story of the SILL: Evaluation, use, reliability, and validity of the Strategy Inventory for Language Learning. Tuscaloosa, AL: Oxford Associates.

Oxford, R. (1996). Afterword: What have we learned about language learning strategies around the world? In R. Oxford (Ed.), Language learning strategies around the world: Cross-cultural perspectives (pp. 247-249). Honolulu: University of Hawaii.

Perfetti, C.A. (1985). Reading ability. New York: Longman.

Schmidt, R. (1990). The role of consciousness in second language learning. Applied Linguistics, 11, 129-158.

Schmidt, R. (1995). Consciousness and foreign language learning: A tutorial on the role of attention and awareness in learning. In R. Schmidt (Ed.), Attention and awareness in foreign language learning (pp.1-63). Honolulu: University of Hawaii Second Language Teaching \& Curriculum Center.

Stanovich, K. E. (1980). Toward an interactive compensatory model of individual differences in the development of reading fluency. Reading Research Quarterly, 16, 32-71.

Tomlin, R. \& Villa, V. (1994). Attention in cognitive science and second language acquisition, Studies in Second Language Acquisition, 16, 183-20.

Tsudajuku Daigaku Gengo Bunka Kenkyu Jo Dokkai Kenkyu Group (Reading Comprehension Study Group of the Institute for Research in Language and Culture at Tsuda College [Tsudajukul. (1992). Gakushusya chushin no dokkai shido [Learner-centered reading instruction]. ACT: Taishukan. 
Winograd, P. \& Hare, V.C. (1988). Direct instruction of reading comprehension strategies: The nature of teacher explanation. In C. Weinstein, E. Goetz, \& P. Alexander (Eds.), Learning and study strategies: Issues in assessment instruction and evaluation (pp. 121-139). San Diego: Academic Press.

Yamato, R. (1997). Eiken 2-3 kyu reberu gakushusya no dokkai sutorategi ni taisuru ninsiki to siyo no sai [Difference between awareness and real use of reading strategies among STEP 2nd to 3rd grade learners]. STEP Bulletin, 9, $60-71$.

(Received January 15, 1999; revised July 28, 1999) 